\title{
BA asserts itself in the defence of British science
}

\section{Belfast}

THE British Association for the Advancement of Science (BA) seems to have rediscovered its role as the defender of British science. At their annual meeting last week, the BA's officials announced that they would be keeping a close watch on the performance of the government's new committee, the Advisory Council on Science and Technology (ACOST), which they consider crucial for the future.

To earn the support of the scientific community, the BA says, the new arrangements will have to lead to real improvement in the factors that have led to such a decline in the morale of the scientific community in recent years. This means the government must "provide additional resources for scientific research and development", and also demonstrate real ministerial support for science and technology at the highest level.

Recent developments, including the resignation of $\mathrm{Mr}$ Roy Gibson as director of the British National Space Centre, are not encouraging, says the BA's president, Sir Kenneth Durham. That incident high-

\section{More condemnation of UK science policy}

\section{Belfast}

ThE pressure group Save British Science (SBS) has made its mark here. Dr John Mulvey, secretary of SBS, says the British government's new policies are but "manoeuvres designed to cope with inadequate funding".

In particular SBS wishes to see:

- National investment in civil research and development increased to 2.5 per cent of gross domestic product within 5 years.

- The University Grants Committee's side of the dual-support system restored and research council budgets increased to enable them to 'target' exploitable topics.

- Industry encouraged to spend more on civil research by effective measures - tax credits for instance - not simply by exhortation.

- The broader integrated science curriculum in schools - a welcome development supported by the money to provide enough teachers and equipment for it to succeed.

- Government plans for a greater than 4 per cent increase in the proportion of young people graduating from universities and polytechnics by the year 2000 .

The SBS view, in short, is that Britain's record in research has been, and still is, outstanding, but that the onus is on the government to turn this success to industrial and economic benefit. Charles Wenz

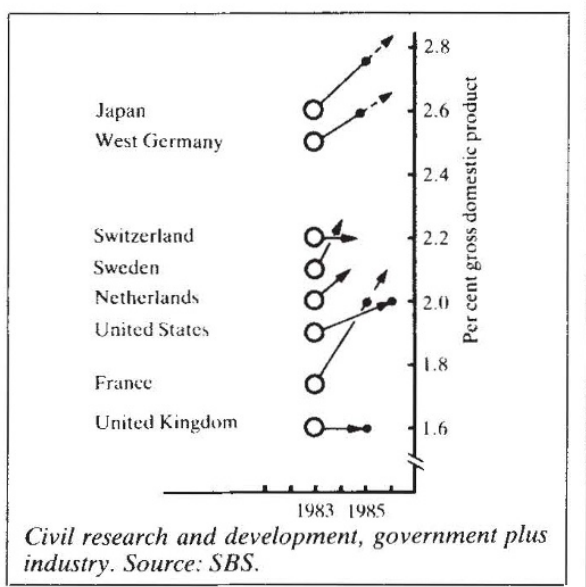

lights a difference of opinion between the government and its critics about the respective roles of government and industry in supporting the two arms of research and development. One reason for the government's reluctance to set aside extra money for space research is said to be disappointment that industry is not itself spending more on research. But in the view of companies such as British Aerospace, some of the important work is too risky for the companies to undertake - and too dependent on decisions taken by international bodies such as the European Space Administration. Such research is exactly that which government should be supporting, in the BA's view.

Defence spending will also be monitored closely. The government has not committed itself to cutbacks, only to "review defence R\&D spending". Durham holds out little hope that such a review will lead to much. For one thing, research is a relatively small component of the defence budget, and after inter-service wrangling there may be little left in the research column to be redistributed to the civil side.

The BA's determination to monitor the government's actions is an extension of the 'Science Audit', a procedure now in its third year, which started as a cooperative venture with government to gather an accurate picture of exactly how much was being spent on research, and to what effect. This year in Belfast the Science Audit banner has been used to give a platform to the views of Save British Science (SBS), which points out that Britain's expenditure on civil research and development, as a percentage of gross domestic product, is far lower than that of its main rivals (see graphic). Ironically, the BA was originally founded, in 1831 , largely out of discontent at the state of British science. A similar discontent led to the founding of SBS in 1986 and seems also to be sending the BA back to its roots.

Charles Wenz

\section{AIDS tests compulsory}

London

The Supreme Soviet has taken powers to authorize obligatory tests for AIDS (acquired immune deficiency syndrome), according to a statement by TASS, the Soviet news agency, a week ago. Tests will be administered to both foreigners and Soviet citizens when there are grounds for believing that people have been infected with the virus. Foreigners and stateless persons refusing to be tested when asked are liable to deportation under the regulations. Anybody deliberately exposing others to the risk of infection may be imprisoned for up to 5-8 years.

According to the president of the Soviet Academy of Medical Science, Dr Valentin Pokrovskii, on 17 August, there are some 130 people in the Soviet Union infected with AIDS, most of them foreigners. The only Soviet citizen with AIDS (out of 19 carriers) is said to be responding to treatment with two Soviet medications. In Bulgaria, testing for AIDS has been made compulsory for all newly-weds and pregnant women.

V.R.

\section{Kidney problems}

\section{Bangalore}

Trading in human kidneys has got out of hand in the Indian metropolis of Bombay, prompting the state of Maharastra Medical Council (MMC) to set up a special panel to root out illegal practices in kidney transplants.

Because cadaverous kidney transplants are not performed in India, trading in live human kidneys has become big business in Bombay. Entrepreneurs will offer a package deal on transplant services - a kidney and the necessary surgery - for prices ranging between $\mathbf{R s 1 0 0 , 0 0 0}$

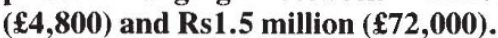

Advertisements will appear in newspapers both soliciting and offering live human kidneys. Typically agents hunt for poor migrant labourers willing to give up a kidney for a mere $R s 3,000-8,000$. Kidneys are normally sold through touts and doctors. Rich patients, often from Arab countries, will travel to India rather than pay more for the same procedure in the United States. Late last year, the Maharastra state health minister reported that large numbers of foreigners are undergoing transplants in some top private hospitals. In Bombay alone there are about 10 kidney transplants each week.

The new panel will seek strict implementation of the Maharastra Kidney Transplant Act of 1983. Once formally constituted, the panel will interview prospective donors and recipients, to protect the legal rights of both. The panel will include a nephrologist, a urologist and a lawyer. The state medical council favours setting up an institute equipped to store the harvested kidneys.

R.R. 